\title{
Hymns across the water ... translated and relocated: The reception of Scottish hymns in translation
}

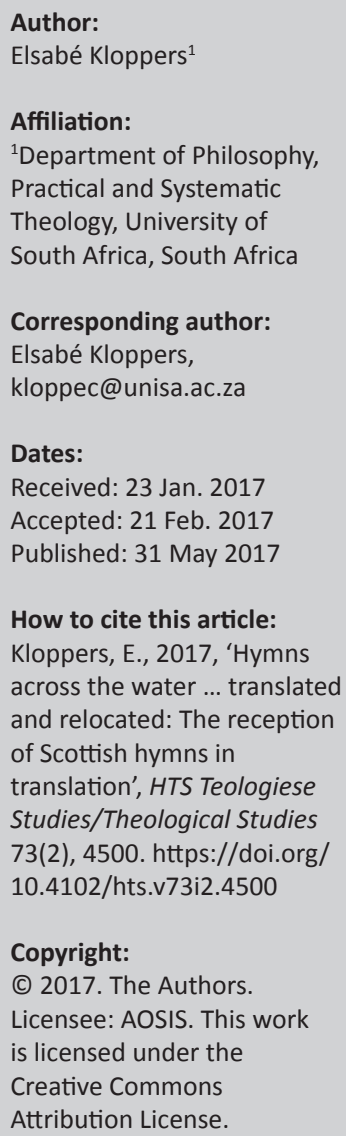

In this article a broad overview of the reception of Scottish hymnody in translation is given. Considering the pivotal role the metrical Psalms used to play in the Scottish churches, they are considered first. Only one metrical Psalm made it to be translated widely and to be included in hymnals over the world. It is the metrical setting of Psalm 23, The Lord's my Shepherd, paired to the tune of Scottish origin, CRIMOND. It is argued that the metrical psalm owes much of its popularity to the tune. A hymn with a text from the Scottish Paraphrases, paired to a Scottish tune, DUNDEE, and for long the only hymn in the Afrikaans churches with a Scottish connection, is discussed with regard to its reception in these churches. It serves as an example of how a hymn could be translated and relocated and function in a new context. In an overview of Scottish hymns translated and included in the newest hymnals in other countries, such as the Netherlands and Norway, it is shown that primarily hymns and songs of the Iona Community are translated and included in the newest hymnals, with John Lamberton Bell being the main exponent as text, hymn and song writer.

\section{Introduction}

In this article a broad overview of Scottish hymnody in translation is given. ${ }^{1}$ Considering what 'Scottish hymnody' would be, the metrical Psalms would come to mind first, because of the pivotal role they used to play in the Scottish churches. A specific Scottish tune could indicate that a metrical psalm stems from the Scottish Psalter and that it is not a translation from the original Hebrew or any other language. Following the metrical psalms, the Scottish Paraphrases would be relevant and thereafter other hymns of Scottish origin. 'Scottish origin' would be texts written originally by people who were born in Scotland and which were later translated into other languages, as well as tunes written by composers born in Scotland. Scottish folk tunes used for hymns are also very relevant. The author writes primarily from a South African perspective, informed by a broad knowledge of Scottish hymnody, gained in almost a year of using Church Hymnary (4th Edition) (CH4) attending and leading worship in Scotland and continuously studying the material included. Regarding texts which were translated, the focus is on the languages in which the author is competent (Afrikaans, German and Dutch, apart from English), but reference is also made to the reception of hymns, translated and included in hymnals in other languages, such as French, Norwegian, Swedish, Finnish and Mandarin. ${ }^{2}$

\section{Scottish metrical Psalms: The Lord's my shepherd, I'll not want - CRIMOND}

The first Scottish Psalter of 1564 was a psalter based to some extent on the Anglo-Genevan Psalter of 1561, the work of John Knox (ca. 1514-1572) and his assistants. It contained English versions, sometimes modified, but also 46 by Scottish writers (Temperley 2013). Included was the wellknown paraphrase of Psalm 100, 'All people that on earth do dwell', by William Kethe (died 06 June 1594), who was a native of the Scottish Borders. Translations of this psalm, however, or of other Scottish metrical psalms, seem to be non-existent in the languages mentioned above, namely Afrikaans, German and Dutch. A clear reason would be that the churches where the Dutch- and Afrikaans-speaking people worship, and for whom the singing of psalms used to be very important, had their own history and corpus of psalms, which also developed from the Genevan Psalter. The German churches also have their own traditions. One metrical psalm from Scotland, however, is translated into numerous languages, and included in hymnals over the world. It is the 'iconic version' of 'The Lord's my shepherd, I'll not want,' which was included in The Psalms of David

1.This article is the first part of a plenary paper presented in St Andrews, Scotland, at the 80th Anniversary Conference of the Hymn Society of Great Britain and Ireland, July 2016.

2.Earlier translations for churches in China, Taiwan, Korea and India, exported primarily through the work of missionaries in the 19th century, would make the scope too wide and are not included. They are referred to in the second article. 
in metre, authorised by the Church of Scotland General Assembly in 1650, and which, according to Ian Bradley, 'perhaps illustrates that good things can come out of committees' (Bradley 2013). ${ }^{3}$ This paraphrase of Psalm 23 is the Scottish metrical psalm most known over the world. Its late 20th century fame outside Scotland, however, is almost entirely owing to the tune CRIMOND. Sung by the popular Glasgow Orpheus Choir in the Queen's Hall in London and played on the 'wireless', it was also chosen for the wedding of Princess Elizabeth in 1947 (Watson 2013). ${ }^{4}$ The tune CRIMOND is now 'indissolubly' linked with this metrical setting of Psalm 23 (Bradley 1997; 2010:143). The recording by the Glasgow Orpheus choir was also heard quite often on the radio in South Africa on Sunday afternoons.

The first appearance of CRIMOND in an Afrikaans hymnal in 1976 (Psalms en Gesange 1976), strangely was not paired to Psalm 23, but was set to a text from Revelation $21,1-7.5$ The reason could be that another setting of Psalm 23 could have been seen as 'competition' for the 'standard' version at that time, which was a part of the (canonised) corpus of 150 Psalms set to metre by the 'canonised' poet at that time, JD du Toit (Totius). ${ }^{6}$ The hymn immediately became part of the top five of that hymnal. The text is touching (as most hymn texts from Revelation 21 probably would be), but the tune contributed much to its immediate popularity, showing that there is something in the tune that just 'speaks to people'. A translation with Psalm 23 and CRIMOND paired together is included in the current official hymnal of the Dutch Reformed Churches, Liedboek van die Kerk (2001).? At funerals where Afrikaans- and English-speaking people worship together, the texts are often sung in both languages.

Apart from the version in Afrikaans, translations of this metrical version of Psalm 23, set to CRIMOND, have appeared in many other official hymnals. In hymnals published only after 2000, there is (to name a few examples), a Korean version in Chansong gwa yebae/ Come, Let Us Worship: the Korean-English Presbyterian hymnal (2001) published in the USA; a French version in Alléluia $(2005)^{8}$, of the Reformed church in France; a version in Esperanto in TTT-Himnaro Cigneta (2009), the largest online Esperantolanguage hymnsite; a Mandarin version in Seng-Si, the official Hymnal of the Presbyterian Church in Taiwan (2009); a Dutch version in Liedboek. Zingen en bidden in huis en kerk (2013); and another Dutch version by Sytze de Vries, Is Hij mijn herder, niets ontbreekt, published more recently at number 29 in his songbook

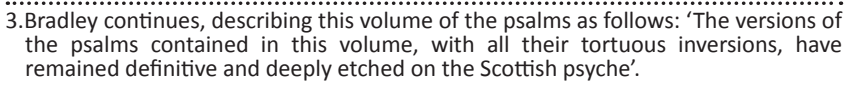
the psalms contained in this volume, with all their tortuous
remained definitive and deeply etched on the Scottish psyche'.

4.In many books the tune has been credited to Jessie Seymour Irvine (1836-1887) but more recent research has suggested that it was almost certainly by an Aberdeen composer, David Grant (see Johnson 1988:38-42). J. Richard Watson (2013c). Ian Bradley $(1997 ; 2010: 143)$ also refers to the discussion.

5.The Afrikaans text by Izak de Villiers: Ek sien 'n nuwe hemel kom (Gesang 177).

6.See Kloppers $(2003 ; 2012 ; 2013)$ for the role of the metrical Psalms in the Afrikaans churches and the importance of the poet JD du Toit, with regard to his versification of the 150 Psalms.

7.The Afrikaans text by Elsabé Kloppers.

8.One of only two hymns with a Scottish connection in this hymnal - the other is Angels from the realms of glory, with a text by James Montgomery, born 1771 (in Ayrshire, Scotland) and died in 1854.
Het liefste lied van Overzee 2 (2015). German versions appear in supplements to the official hymnal of the churches in Germany, Evangelisches Gesangbuch (1993). ${ }^{9}$ It is clear that the metrical version of Psalm 23, set to CRIMOND, is the Scottish hymn or metrical Psalm translated and relocated the most.

\section{Translated and relocated from the Scottish Paraphrases: O God of Bethel, by whose hand - DUNDEE}

In the first hymnal in Afrikaans (Psalms en Gesange 1944), the Afrikaans text for $O$ God of Bethel, written originally by the Englishman Philip Doddridge (1702-1751) $)^{10}$ and paired (indissolubly) to the tune DUNDEE, was the only hymn with a tune of Scottish origin. The tune first appeared in the 1615 edition of the Scottish Psalter. Called a 'French' tune (and currently known in Scotland primarily by the name FRENCH), DUNDEE was one of that hymnal's 12 'common tunes', which means it was not associated with a specific psalm. ${ }^{11}$ The tune is mentioned in The Cotter's Saturday Night by Robert Burns alongside the names of other beloved psalm tunes, which are engraved in the Scots' memory (quoted in Kloppers 2012).

Tom Troeger (2010) starts a chapter in his book on sermons inspired by hymns, music and poetry (called Wonder reborn) with a scene, which has a familiar ring: his mother, sitting at the piano, playing hymns they never sang in church. Originally from South Carolina in the USA, she complained that they did not sing the hymns she knew and that they did not sing with the warmth they used to sing. The difference was illustrated by the contrast between 'In the Garden', which she played with substantial rubato, and 'O God of Bethel by whose Hand', which they sang with a steady beat to the tune, DUNDEE, in his childhood church in upstate New York. As a child he immediately recognised the difference in the sound and 'with a child's way of knowing', he sensed two musical characterisations of God in the contrasting tunes and rhythms. 'In the Garden' made him picture his great-aunt's flower garden. 'O God of Bethel by whose hand' always brought to mind a picture in his history textbook of the pilgrims in New England, simply because the first verse speaks of 'this weary pilgrimage' (Troeger 2010:29).

The translated version of the hymn, O God van Jakob, deur $u$ hand word heel $u$ volk gevoed, was one of the most popular hymns of the Afrikaans-speaking people of my childhood. ${ }^{12}$

9.For example, in Singt Jubilate. Lieder und Gesänge für die Gemeinde (2013), a hymn book for the Berlin-Brandenburg church. Translation by Charlotte Sauer 1954.

10.Philip Doddridge was born in London - thus not of Scottish descent, but I was informed by a colleague in Aberdeen, Dr Graham Deans, that Doddridge was in fact the holder of two Aberdeen D.D. degrees, awarded by each of that city's collegeuniversities, which shows that he was held in high esteem by the Scots. The text was written in 1745, but first published in Scottish Paraphrases, 1781. In CH4 it is included at number 268 .

11.The name of the tune comes from the city of Dundee, known as the 'Scottish Geneva' during the era of the Scottish Reformation. DUNDEE in Psalter Hymnal Handbook, online version (Brink \& Polman 1998).

12.In South Africa, Dutch versions probably were sung already in the late 19th century. In the early 20th century it was printed in Halleluja (1903). An Afrikaans version dates from 1931 (Gerdener) with versions included in the official hymnals by E.C. Pienaar (1944), altered by Gerjo van der Merwe (Psalms en Gesange 1976) and slightly altered again for Liedboek van die Kerk 2001. 
It was a hymn for people who believed they also had a history of 'pilgrimage' with the Great Trek and who strongly believed they had a God-given calling. Through the use of this hymn (sung also at religio-political gatherings, as argued by Kloppers 2003, also by Cilliers 2010), the hymn received a political colour: ' $u$ volk/ thy people' would denote the white Afrikaans-speaking people, fed by and being led by God and thus forming a certain spiritual identity, coinciding with a cultural or political identity. Ideas and ideologies certainly can be strengthened through repetitive use in a certain way. One cannot prevent, however, that the open spaces in a text are filled with meaning by the singers singing in a specific context and amid certain circumstances. It is shown excellently by Tom Troeger's anecdote, where he heard the hymn in the American context, with a specific history of the pilgrims associated with it; or sung by the Afrikaans-speaking people, hearing it in their specific context; ${ }^{13}$ or the Scots, singing this hymn from the Scottish Paraphrases - without doubt also hearing it in their context and ascribing their own meaning to 'thy people' and 'our fathers'. It is one of the reasons why texts are translated and hymns get relocated: they can be filled with new meaning in new situations and in new contexts. Filling in the open spaces is inevitable and also necessary, but my appeal made earlier also remains: that critical reflection on the use of psalms, hymns and songs is necessary in order to recognise the own biases, underlying motives and subconscious cultural, political and ideological influences playing a role in the processes of singing hymns and psalms (Kloppers 2012).

Strictly speaking, the text should not be discussed here, as it is not written by a Scot, but its reception was via the Scottish Paraphrases. ${ }^{14}$ I therefore make an excursion, briefly discussing important differences in the translation. The first two lines are the same: O God of Bethel! by whose hand/ thy people still are fed, except for 'Bethel', which became 'Jacob': O God van Jacob, deur $U$ hand, word heel $u$ volk gevoed ... It would be impossible to find a word that rhymes with 'pelgrimstog' [the Afrikaans translation for 'pilgrimage'], so the third and fourth lines, who through this weary pilgrimage/hast all our fathers led, became: U het weleer op see en land ons vadere behoed (in the past you protected our fathers on sea and on land). In Afrikaans it became a hymn saying something to people whose fathers [sic] have travelled across oceans to a country where vast oceans meet - indeed a hymn, which itself has travelled across the water. In the second stanza, however, 'God of our fathers'

13.1 have argued that this hymn and others were used in a religio-political context (2003), but personally l associated it much stronger with singing in church, knowing that ' $\mathrm{u}$ volk/ your people' denote all believers, all God's people. 'Our fathers', however, did mean to me our forebears, coming to Africa because of their faith. It was strengthened by the idea of being a descendant of the French Huguenots, It was strengthened by the idea of bein
who were persecuted for their faith.

14.In the late 18th and 19th centuries, ministers of Scottish descent had a prominen influence in the Dutch Reformed Churches in the Cape and broader in South Africa. Van der Walt and Cillie (2005:91) refer to the reminiscences of Maria Neethling, wife of the Rev Neethling of Stellenbosch and one of the daughters of the influential Reverend Andrew Murray (1828-1917) (holder of a Magister and an Honorary Doctorate from the University of Aberdeen and another Honorary Doctorate from the University of Cape Town). Writing in 1909, Maria Neethling Doctorate from the University of Cape Town). Writing in 1909, Maria Neethling remembers her youth and how they travelled once in five years by horse-cart from Graaff Reinet to Cape Town, to attend Synod. On their 10-day journey it was customary to sing during the first hour of the morning and the last hour in the evening. Alongside the Dutch psalms and hymns, 'so sacred, so familiar, so tender to us Cape people', she affectionately mentions the Scottish Paraphrases, togethe with other hymnals and hymns - all sung 'long before Sankey or Church Praise or even Bateman existed'. is not taken over directly in the Afrikaans text, neither is God asked to 'be the God of their succeeding race'. The exclusive language of the original is tempered in the translation. The original second stanza reads as follows:

Our vows, our prayers, we now present

before thy throne of grace:

God of our fathers! be the God

of their succeeding race.

The meaning attached or assigned to the word 'race' in 1745, when the hymn was written, would clearly be 'succeeding generation'. When this stanza was translated into Afrikaans in the 1930s and 1940s, however, the pitfall of using the word 'race' (ras in Afrikaans) was avoided. Stanzas two, three and four differ in content, but they agree in the idea of God protecting God's people. Stanza five in Afrikaans speaks to the one who determines our destiny in good times and in trouble and ends with: You are our Father and our God - only you are truly good. It is quite different from the original English text: and thou shalt be our chosen God, our portion evermore. In the original it seems to be the completion of a conditional clause, referring back to the ending of the second stanza: asking God and waiting on God to be God of the succeeding race, and if it was fulfilled, God would be our chosen God. Even if it is not read as a conditional clause to be fulfilled, there would have been much critique if these phrases had been translated directly into Afrikaans, and from a political point of view, much would have been read into the link being formed in one's mind by: 'be the God of their succeeding race' - and 'thou shalt be our chosen God'.

It may have been the text, speaking of God's care in the past, in the present and in the future (when all our wanderings cease), which had given the hymn its appeal, also in the USA. But it is even more likely that the tune, DUNDEE, has contributed much to its popularity (see Kloppers 2003 again, on the most popular hymns and tunes in the Afrikaans churches). Tom Troeger remembers it from his childhood and uses it to illustrate that a hymn as a whole (text and tune combined) could tell something and bring certain associations and images to mind. But more importantly: he emphasises that a tune itself, as well as the performance of a tune, can also tell something or bring certain associations or images to mind. DUNDEE is an unassuming tune, but I remember 'with a child's way of knowing', being intrigued by the circular movement in the first part of the melody, hearing something of the movement of the waves, which together with the text, was describing something of the coming of 'our fathers' across the sea - U het weleer op see en land ons vadere behoed also describing something of the movement of time within which people have been living and moving. In the second part, I experienced a feeling of breaking-free and a sense of joy with the upward leap, ${ }^{15}$ followed by the assuring steps downwards and meaningful repetitions of notes. Speaking of God's work and protection in history, it certainly 'has helped'

15. Robert Burns may have had this double leap in mind, when he wrote about Dundee's wild-warbling measures, as it certainly is not true of the other parts of the tune! 
to bring assurance and comfort. ${ }^{16}$ This discussion serves as an example of how a hymn could be translated and relocated, function anew, and receive new meaning in a new context.

DUNDEE was the only tune of Scottish origin in the first Afrikaans Hymnal (1944). CRIMOND was added in the second Afrikaans hymnal (1976) ${ }^{17}$ (as discussed above), and three songs by John Bell (which will be mentioned later) were added in the third official hymnal, Liedboek van die Kerk 2001. ${ }^{18}$

\section{The reception of Scottish material in recent hymnals and hymns books} The Netherlands

In the previous official Dutch hymnal, Liedboek voor de Kerken (1973), only one hymn with Scottish links was included: a translation of Glory be to God the Father ${ }^{19}$ by Horatius Bonar (1808-1889). For the new hymnal in the Netherlands, Liedboek, OR: Zingen en bidden in huis en kerk (2013), specific members from the committee were tasked to find material from abroad. Scotland also came into focus. The gap was filled with 17 more texts - 13 of which were written by John Bell (four of those together with Graham Maule 1958). The four others are: Morning has broken ${ }^{20}$ by Eleanor Farjeon (1881-1965), set to the Gaelic folk melody, BUNESSAN - now a favourite to be translated and included in hymnals over the world; ${ }^{21}$

16.lan Bradley (2010:190-193) refers to a survey by WT Stead around 1898, on 'hymns that have helped', when the Duke of Argyll 'led a chorus of approval for this 'hymns that have helped, when the Duke of Argyll 'led a chorus of approval for this hymn'. It is not known which tune the Duke has had in mind. The setting in $\mathrm{CH} 4$ is SALZBURG, by Joseph Michael Haydn and in the Church of Scotland it now usually (1927) it is set to SALZBURG for the First Tune; and FRENCH (aka DUNDEE) for its Second Tune (No 562) (note by Graham Deans, in E-mail, 4 January 2017). The text sung to DUNDEE got exported to South Africa and other countries.

17. Another tune in the 1976 hymnal is indicated as 'Scottish' (hymn number 220). It is not Scottish in origin, however. It is the tune WINDSOR, also named DUNDEE in Scotland (where 'our' DUNDEE is called FRENCH). Graham Deans sent me the following information on the tune (Deans 2017): 'The melody is exactly as per the Scottish Psalter (1929) where it is named DUNDEE. In Revised Church Hymnary (1927) it is similarly named, but with WINDSOR in brackets. In both books the source is given as Damon's Psalms, 1591. But it is probably an adaptation of a tune source is given as Damon's Psalms, 1591 . But it is probably an adaptation of a tune in Christopher Tye's Actes of the Apostles (1553) [spelling original], so definitely NOT Scottish. It migrated north in 1615 and is one of the Twelve Common Tunes published in Edinburgh by Andro Hart, where he terms it DUNDIE TUNE.' Info from
the Handbook to the Church Hymnary, Moffatt and Patrick (1935:96).

18.AMAZING GRACE was also newly included in the hymnal, Liedboek 2001. Where it is paired to one of his texts ( $\mathrm{CH} 4555 \mathrm{a}$ ), John Bell claims the tune to be a 'Scottish traditional melody'. If so, it may be the most popular tune from Scotland - whethe sung with the text, Amazing Grace, in English or in translated form. Translated versions of the hymn are newly included in the Finnish and Swedish Addenda in Finland (Virsikirjan lisävihko and Sång i Guds värld 2016). In one of the most recent hymnals from the USA, Lift Up Your Hearts: Psalms, Hymns, and Spiritual Songs (2013), the Scottish origin is acknowledged as 'Scottish traditional' - but only at number 670, where it is set to the text, I waited patiently for God, as in $\mathrm{CH} 4$ (No. 31). At the text, Amazing Grace, by John Henry Newton (1725-1807), the first source of the tune in print is given as Virginia Harmony 1831. In the Psalter Hymnal source of the tune in print is given as Virginia Harmony 1831. In the Psalter Hymna Handbook 1988, the tune is described as follows: NEW BRITAIN (also known as AMAZING GRACE) was originally a folk tune, probably sung slowly with grace notes and melodic embellishments. Typical of the Appalachian tunes from the souther United States (italics author) NEW BRITAIN is pentatonic with melodic figures that outline triads' (Psalter Hymnal Handbook 1988: 741). It is also typical of folk songs in Scotland, Ireland and other countries. Dr lan Anderson (e-mail dated 10 January 2017) made me aware of the fact that John Purser, in Scotland's Music, also describes it as of Scottish or Irish origin (Purser 1992/2007). Elizabeth Cosnett solves the problem by calling it 'an American folk melody, possibly based on an earlier Scottish one'. (Cosnett 2013).

19.Translation by the well-known Dutch text writer and poet, Willem Barnard (19202010) and set to REGENT SQUARE by Henry Smart (1813-1879), Liedboek 1973, $\mathrm{Nr} 705$

20.Translation Andries Govaart, Liedboek 2013: 216.

21.The song was made popular in the USA by the folk-singer Cat Stevens, who sang it in the $1970 \mathrm{~s}$. It has been translated into many languages - among others into German by Jürgen Henkys as Morgenlicht leuchtet (in Evangelisches Gesangbuch 455), in Finnish, Nousta sain aamuun, by Matti Kolehmainen, Addendum 2015, Nr 967; in Swedish, Tänk att få vakna, by Ingamay Hörnberg. Swedish Addendum in Finland 2015, Nr 921.
Night has fallen by Tom Colvin (1925-2000);22 While Mary was watching, they hung Jesus high, ${ }^{23}$ by Alison Robertson (1940); and Oh, the life of the world is a joy and a treasure ${ }^{24}$ by Kathy Galloway (1952), set to LIFE OF THE WORLD by Ian Galloway (1952). It means that 16 of the 17 new texts from Scotland were originally written by members of the Iona Community. The remaining text writer, Eleanor Farjeon, was born in Hampstead, England.

Apart from the music composed by John Bell, set to his texts and versions of liturgical pieces, the following tunes from Scotland are included in the Dutch hymnal: LIFE OF THE WORLD, BUNESSAN and CRIMOND, as mentioned already, then the meditative LEWIS FOLK MELODY, set to the translation of Jesus calls us here to meet him by John Bell and Graham Maule, ${ }^{25}$ the Scottish folk tune THE ISLE OF MULL set to the translation of For you the pride from my heart is banished ${ }^{26}$ by John Bell, and GLENFINLAS ${ }^{27}$ set to two texts, one by Willem Barnard, Samen op de aarde (Liedboek 1973:994), and the other by Sytze de Vries, Licht in onze ogen (Liedboek 2013:994) (Light in our eyes). These new hymns and songs have already become popular in the Dutch churches. In content and musical style, they are very different from that which dominated in the previous official hymnal - which appeared 40 years earlier! They surely bring something new to a younger generation. Some of the choices I find a bit strange, compared to what is not included, but it will always be the case. ${ }^{28}$ In some translations I find clashes in the register of the language, sometimes also old-fashioned language clashing with the contemporary feel of a hymn or song.

The most prolific hymn text writer and translator currently in the Netherlands is Sytze de Vries (1945). ${ }^{29}$ Many of his texts are included in the new Dutch Liedboek. His two volumes of Het liefste Lied van overzee $(2012,2015)$ [The most beloved hymns/songs from across the sea $]^{30}$ contain translations of hymns that people heard in cathedrals or churches somewhere in England or Scotland, or other hymns and songs from the British Isles recommended to him.

\section{Translation Andries Govaart, set to MALAWI, arranged by Colvin - DZZUWA LAPITA} Liedboek 2013: 257.

23.Translation by Ria Borkent, set to BASQUE CAROL, Liedboek 2013: 583.

24.Translation Sylvia Kolthof, Liedboek 2013: 880.

25.Translation by Ria Borkent, Liedboek 2013: 975

26.Translation by Roel Bosch, Liedboek 2013: 131a. CH4 89.

27.GLENFINLAS was composed by Kenneth George Finlay (1882-1974) born in Aberdeen, Scotland. Originally an architect, Finlay switched to a music career in Aberdeen, Scotland. Originally an architect, Finlay switched to a music career in
1928 and studied at the Royal Academy of Music, then at the Teachers' Training 1928 and studied at the Royal Academy of Music, then at the Teachers Training College, Jordanhill, Glasgow,

28.An example is While Mary was watching, they hung Jesus high, by Alison Robertson and translated by Ria Borkent. I found the portrayals of the crucifixion too graphic and too explicit, but when I compared the texts, I saw that the problems were in the translation, more so than in the original text. I do not deny that this hymn (in the original language, especially) can function meaningfully in the liturgy, especially in Lent and Holy Week.

29.See interview with Sebastiaan 't Hart 2015.

30.There is a much smaller sea between Britain and the Netherlands, than between Britain and South Africa, but because South Africa was colonised by Britain, British influences in hymnody used to be much stronger in the country further away, than in the country just across the channel. The situation has been changing in the past few years. 
The following are translations of texts set to tunes from Scotland, included in Het liefste Lied, vol. 2:

1. The Lord's my shepherd, Psalm 23 (Is Hij mijn herder, niets ontbreekt, nr 28), set to BROTHER JAMES' AIR, by James Leith Macbeth Bain (c. 1840-1925) (It is the same text as set to CRIMOND at nr 29).

2. As pants the heart for cooling streams, Psalm 42 by Nahum Tate (1652-1715) and Nicholas Brady (1659-1726) (Zoals een hert naar water smacht, nr 64) set to MARTYRDOM (Fenwick), composed by Hugh Wilson (1766-1824) and arranged by Robert Archibald Smith (1780-1829) (CH4 32) (Watson 2013b). ${ }^{31}$

3. We lay our broken world, by a song writer who lives in Scotland, Anna Briggs (1947) ${ }^{32}$ (Vol zorgen leggen wij, nr 51) set to GARELOCHSIDE (CH4 721), by Kenneth Georg Finlay (1882-1974) (the text writer mentioned at footnote 27).

4. Come and find the quiet centre, by the text writer from New Zealand, Shirley Erena Murray (1931) (Zoek de stilte en vind ruimte, $\mathrm{nr}$ 65), set to LEWIS FOLK MELODY (CH4 716).

5. Will you come and follow me, by John Bell (1949) and Graham Maule (1958) (Als ik jou bij name roep, nr 4), set to KELVINGROVE, a Scottish folk melody (CH4 533).

6. This is a day of new beginnings by Brian Wren (1936) (Wij mogen hier opnieuw beginnen, nr 59) set to CANONMILLS by Douglas Galbraith (1940) (CH4 526).

De Vries made another translation (to my mind more lyrical than the one in Liedboek 2013) of Morning has broken (Daglicht gaat stralen, nr 12), set to BUNESSAN. He also translated Immortal, invisible, God only wise (Hoe heerlijk, hoe heilig, nr 32). The original text is by Walter Chalmers Smith, who was born in Aberdeen 1824 (died 1908), ordained as a pastor of the Free Church of Scotland and later pastor of the Free High Church, Edinburgh. The hymn appears in almost every hymnbook, but admittedly, the popularity of the hymn should be attributed to the Welsh tune ST. DENIO.

In Het liefste lied, Deel 2, De Vries has included translations of two texts by Horatius Bonar (1808-1889), I heard the voice of Jesus say (CH4 50) (Ik hoorde hoe Hij tot mij sprak, nr 26) ${ }^{33}$ and Fill thou my life (CH4 183) (Maak heel mijn leven tot een lied, nr 37). Horatius Bonar, a minister of the Free Church, was the greatest Scottish hymn writer of the 19th century. He wrote more than 600 hymns. His hymns were not sung in his own congregation as they were vetoed by the Kirk Session, which allowed only Metrical Psalms to be sung, but they spread to other parts of the world through his cooperation with Moody and Sankey and further on through the work of the missionaries and were translated into many languages (Bradley 1997; 2010:182). Various translations of his texts into Mandarin and Korean are still included in hymnals.

31.MARTYRDOM was originally an 18th century Scottish folk melody used for the ballad 'Helen of Kirkconnel'. Hugh Wilson (1766-1824) (b. Fenwick, Ayrshire)
adapted MARTYRDOM into a hymn tune in duple meter around 1800. Robert Archibald Smith (1780-1829), rewrote it in triple time, published it, and gave it its name. The tune in triple time gets published more often. (Watson 2013b)

32. Originally from Newcastle-upon-Tyne, Anna Briggs is a long-time member of the Iona Community.

33.Set to KINGSFOLD by Ralph Vaughan Williams.
Hymns and songs are translated, often because texts would speak to people, but even more often because a tune would speak to people in the first place. Tunes touch the innerbeings of people more immediately. Most of the tunes paired with translations mentioned above are quite touching - one could say, tunes containing quite a high level of emotion or nostalgia, which certainly speak stronger to people who have grown up with them. MARTYRDOM is one of the tunes mentioned above, which reminded me of a telling e-mail in 2012, received from Margaret Anderson, a person with a deep interest in the history and culture of Scotland, responding to the article I wrote on the role of the metrical psalms in the Church of Scotland and the similarities with the Afrikaans Dutch Reformed churches. She wrote that she not only appreciates the importance of the Psalms throughout their history, and therefore values the tradition, but also admits that congregational Psalm-singing is not integral to her sense of identity in a faith context. She was raised in the community of Plymouth Brethren, who did not use the Metrical Psalms; therefore, the words of the Metrical Psalms are not part of her conditioning and upbringing. Many of the hymns in the Brethren hymn book, however, would be set to Psalm tunes. These tunes became part of her being. Her description of the role of these tunes in the history of her family and in her life reflects much nostalgia and love for the Psalm tunes. She writes primarily about MARTYRDOM, but DUNDEE is also mentioned:

Although congregational Psalm-singing (though I appreciate it) is not integral to my sense of identity in a faith context, the old Psalm TUNES most definitely are important to me as a daughter, granddaughter, mother - and now grandmother! My maternal grandmother's roots were in the United Presbyterian Kirk, although her community (the fishing towns of the Moray Firth) were also very influenced by the Moody and Sankey movement of the 19th Century ... She was the oldest of 16 children, so she probably often sang to younger brothers and sisters as they went to sleep, and with her own family, and also her grandchildren, her lullaby was always the same Psalm tune-Martyrdom. It was sung to typical lullaby words, 'Hush-ye ba ba louie...' I don't know how far back this tradition of using Martyrdom (or 'Martyrdoom' as my grandmother pronounced it) as a lullaby went, but my mother certainly sang it to me and to my sister, and I instinctively sang it to my own children, and now I have found myself singing and humming Martyrdom when rocking Zofia or walking with her over my shoulder! But I should add that I didn't restrict myself to Martyrdom with my own children - almost without realising, I'd be humming a range of the wholesome, beautiful, haunting familiar old Psalm tunes to them - Stracathro, Kilmarnock, Glasgow, French, Dundee, Dunfermline, Irish, Ballerma ... ${ }^{34}$ Martyrdom in particular is for me the repository (and expression) of a great many memories and a great deal of emotion. (Anderson 2012)

\section{Hymns and songs from the lona Community included in newer hymnals}

The hymns and songs by John Bell included in the new Dutch hymnal, as well as those by other members of the Iona Community's Wild Goose Worship Group, are mentioned above.

34. 1 love to add that their three children, raised on the Psalm tunes, are all now professional musicians, playing in orchestras over the world. 
John Bell, the leader of the group, is a Church of Scotland minister, employed full-time by the Iona Community. He certainly has been the most prolific and influential Scottish hymn writer over more than three decades. His songs and hymns (as well as those of other members of the Iona Community) address social issues, suffering, justice, healing, discipleship and many other themes. With his own tunes, or set to traditional Scottish folk tunes, they have been very popular and found their way into most modern hymnals. They appear in Dutch, as shown above, but also in Finnish, Swedish, Norwegian, Spanish and many other languages. Information from various hymnals published after 2000 are given chronologically. Translations of three songs by John Bell included in the Afrikaans Hymnal, Liedboek van die Kerk (LvdK) 2001, are Kom, Heil'ge Gees [Come, Holy Spirit] (LvdK 166); Brood en wyn is tekens [Bread is blessed and broken] (LvdK 298); and Kom kyk! Kom kyk! Kyk, alles word nuut! [Behold, behold, I make all things new] (LvdK 444).

In Sèng-Si (2009) from Taiwan, five items from the Iona Community, translated into Mandarin, are included: Holy holy holy, Lord of power (Nr. 294), God to enfold you (Nr 420), both by John L. Bell, Jesus Christ is waiting (Nr 83), text John Bell and Graham Maule, set to NOEL NOUVELET, Night has fallen (Nr 423) from Malawi and Jesu! Jesu! Fill us with your love (Nr 78), a folk song from Ghana, by Tom Colvin. ${ }^{35}$

Eight songs from Iona are included in the official Norwegian hymnal, Norsk Salmebok (2013). Seven are texts by John Bell or John Bell and Graham Maule: ${ }^{36}$

In a Byre near Bethlehem (Norwegian: I et skur ved Bethlehem)

Christ has risen while earth slumbered (Norwegian: Krist stod opp for dagen demret)

O Lord, our Lord, throughout the earth (Norwegian: All skapnings Herre, allmakts Gud)

Whoever lives beside the Lord (Norwegian: Sjå, den som bur i livd hjå Gud)

When God almighty came to earth (Norwegian: Da Herren kom til denne jord)

Will you come and follow me (Norwegian: Det er navnet ditt jeg roper)

God to enfold you (Norwegian: Gud er din hoile)

The eighth song from Scotland included in Norsk Salmebok 2013 is Love is the touch of intangible joy (Kjærleik er gleda, uendeleg sterk), text and tune by Alison M Robertson. ${ }^{37}$

In the Addendum, Virsikirjan lisävihko 2016, for the Finnishspeaking people in Finland, one song from Iona is included:

35. My sincere thanks go to Lionel Li-Xing Hong from Taiwan, who sent me various indices and scans of all material in Seng-Si, which could be of Scottish origin.

36.Information originally sent by Vidar Kristensen, the Projectmanager for the Norwegian Hymnal, in various e-mails dated from 30 June to 4 July 2016.

37.Translated by Heidi Strand Harboe in 2005. With the focus on love, 'the force that no fear can destroy', it is a choice from the same text writer, quite different from hat for the Dutch that for the Dutch hymnal, While Mary was watching, they hung Jesus high. largued previously that it is hard to translate the monosyllabic word 'love into the A why this text was not easily translated into Dutch: the prominent position of liefde [love] as the first word in each line, on an ascending tune, would bring the stress on both syllables and create a bad relationship between text and tune.
Etsi, kutsu minutkin [Take, O take me as I am] number 914, by John Bell. In the Addendum to the hymnal for the Swedishspeaking people in Finland (Sång i Guds värld 2016), four songs are included: Möt mig nu som den jag är, nr 917 [Take, O take me as I am] and Här ser vi nu Guds lamm, nr 872 [Behold the Lamb of God], texts and music by John Bell, as well as Lovsjung vair Gud, nr 804 [set to a folk tune from Scotland] and Sjung med glädje till Guds ära, nr 826, set to LAUDA ANIMA by John Goss (1800-1880), both texts by John L Bell and Graham Maule. ${ }^{38}$

It is interesting that the choice of items from the Iona Community for the various hymnals is fairly random and that there is much variety in what is included. A book with translations into German, Freut euch und singt was published at the end of 2015. It contains a hundred items, varying from longer hymns and psalms, to choruses, liturgical chants and a number of items from the repertoire of world song. Considering the influence of Iona material, it is unfortunate that some of the translations are a bit disappointing, with inversions which could have been avoided, clichéd rhyme, or a bad relationship between text and tune. That said, the material from Iona surely can fill a niche, also in Germany, where there is a strong heritage of hymnody, stretching from the times of the Reformation, but where a need exists for more contemporary songs addressing social issues of our time, for songs which have a meditative feel, for new liturgical material, for material allowing more participation or participation in a different way. Through workshops, led by John Bell or by others who have attended his workshops, the material is actively promoted and finds a wide audience.

\section{Conclusion}

Tunes contribute much to the popularity of hymns and often a tune is the prime reason for a text to be translated and relocated. An overview of Scottish hymns and songs translated and included in the newest hymnals proves that primarily hymns and songs of the Iona Community are translated and included in the newest hymnals, with John Bell being the main exponent. Bell abundantly uses folk tunes from Scotland, which have an emotional quality that speaks to people and which certainly contributes to the popularity of Iona material. More tunes are exported from Scotland, than texts. Ian Bradley's description of the essence of Scottish hymnody may be an indication why not more of the older Scottish hymn texts got translated: the harsher nature of the landscape of Scotland may be reflected too strongly, with the hymnody showing a 'preference for the "steep and rugged pathway" over the "green pastures"':

The hymns written and sung by Scottish Christians have been generally more rugged, strenuous and theologically nuanced than those of their co-religionists south of the Border, reflecting the harsher nature of their physical landscape, the greater seriousness and intensity of their faith, and the intellectual

38.In the Swedish addendum (Sang $i$ Guds värld), other inclusions from Scotland are BUNESSAN [Morning has broken], AMAZING GRACE (if it would be accepted that the tune is originally from Scotland, or then 'shared origin') and a hymn by that the tune is originally from Scotland, or then 'shared origin') and a hymn by John Brownlie (born in Glasgow 1857, died 1925), O God, Thy glory gilds the sun translated by Anders Frostenson as Guds son en gang imorgonglans, $\mathrm{nr}$ 858. The origin of the hymn is wrongly given as England. Apart from the song by John Bell, BUNESSAN and AMAZING GRACE are included in the Finnish addendum, Virsikirjan lisävihko 2016. 
calibre of their ministry. Scottish hymn writers may not have had the smooth elegance or artistic accomplishment of their English counterparts ... but they have made up for this in evangelical fervour and theological depth. (Bradley 2013)

\section{Acknowledgements Competing interests}

The author declares that she has no financial or personal relationships which may have inappropriately influenced her in writing this article.

\section{References}

Alléluia! Avec le Christ dépasser les frontières, 2006, Editions Olivétan, Lyon. Anderson, M., 2012, email, 20 September, verylikeawhale55@hotmail.com Bradley, I., 2010 (1997), Abide with me: The world of Victorian hymns, Faber and Faber, London, p. 91.

Bradley, I.C., 2013, 'Scottish hymnody', in The Canterbury dictionary of hymnology, Canterbury Press, viewed 24 May 2016, from http://www.hymnology.co.uk/s/ scottish-hymnody

Brink, E. \& Polman, B., (eds.), 1998, Psalter Hymnal handbook, CRC, Grand Rapids, viewed 25 June 2016, from http://www.hymnary.org/text/o_god_of_bethel_by_ whose_hand

Chansong gwa yebae/ Come, Let Us Worship. The Korean-English Presbyterian hymnal, 2001, Geneva Press, Louisville.

Church Hymnary. Fourth Edition (CH4), 2005, Church of Scotland and United Free Church of Scotland 2005, Canterbury Press, Norwich.

Cilliers, J., 2010, 'Das Klingen des Lebens. Liedübertragungen als Transfer religiöser Kulturpraxis', Berliner Theologische Zeitschrift 28(2/2011), 279-299.

Cosnett, E., 2013, 'Amazing grace! (how sweet the sound)', in The Canterbury dictionary of hymnology. Canterbury Press, viewed 10 January 2017, from http:// www.hymnology.co.uk/a/amazing-grace!-(how-sweet-the-sound)

Deans, G., 2017, emails, 04 January and 10 January, graham.deans@btopenworld.com De Vries, S., 2012, Het liefste Lied van overzee, Skandalon, Vught.

De Vries, S., 2015, Het liefste Lied van overzee. Deel twee, Skandalon, Vught. Evangelisches Gesangbuch, 1995, Evangelische Landeskirchen in Baden, Karlsruhe. Freut euch und singt, 2015, Strube/ Wild Goose Publications, München.

't Hart, S., 2015, "'Zingen is belangrijk, daar blijf ik op hameren". In gesprek met Sytze de Vries', Muziek en liturgie, 84(4), 47-50.
Halleluja: Liederen voor Zondagskolen, Strevers- en Jongelingsvereenigingen, Conferenties en Bijzondere diensten (1903), (Bijeengebracht door Charles Murray), Z.A. Bijbel Vereeniging, Kaapstad.

Johnson, R., 1997, 'How far is it to Crimond?', Bulletin of the Hymn Society of Great Britain and Ireland 176(July 1988), 38-42.

Kloppers, E., 2003, “'Laat Sions berg weerklink van vreug, laat Juda's dogters hu verheug." Hymns, Hymnals and the National Identity of the Afrikaner', in C. Kück \& H. Kurzke (Hrsg.), Kirchenlied und nationale Identität, pp. 206-221, Francke, Tübingen.

Kloppers, E., 2012, 'People of God? Singing the psalms as a reflection of identity Perspectives from South Africa and Scotland', NGTT 53(2), 159-167.

Kloppers, E., 2013, 'Die Wirkung von Psalm 130 im Leben der Reformierten in Südafrika', HfK-aktuell, Heidelberg Hochschule für Kirchenmusik 8(December), 44-49.

Liedboek van die Kerk, 2001, NG Kerk Uitgewers, Kaapstad.

Liedboek voor de Kerken, 1973, G van der Leeuw-Stichting, Amsterdam.

Liedboek - zingen en bidden in huis en kerk, 2013, BV Liedboek, Zoetermeer.

Moffatt, J. \& Patrick, M. (eds.), 1935, Handbook to the Church hymnary, revised edition with supplement, Oxford University Press, London.

Norsk salmebok. For kirke og hjem / For kyrkje og heim, 2013, Eide Forlag AS, Stavanger.

Psalms en Gesange, 1944, Suid-Afrikaanse Bybelvereniging, Kaapstad.

Psalms en Gesange, 1976, NG Kerk Uitgewers, Kaapstad.

Purser, J., [1992] 2007, Scotland's music: A history of the traditional and classical music of Scotland from early times to the present day, Mainstream Publishing, Edinburgh.

Sång $i$ Guds värld - Tillägg till Svensk psalmbok för den evangelisk-lutherska kyrkan i Finland, 2016, Fontana Media, Helsinki.

Temperley, N., 2013, 'Scottish psalter', in The Canterbury dictionary of hymnology, Canterbury Press, viewed 24 May 2016, from http://www.hymnology.co.uk/s/ scottish-psalter

Troeger, T.H., 2010, Wonder reborn: Creating sermons on hymns, music and poetry, Oxford University Press, Oxford.

Van der Walt, J.J.A. \& Cillié, G., 2005, 'Aspects of Afrikaans music', in C. Lucia (ed.), The world of South African music: A reader, Cambridge Scholars Press, Newcastleupon-Tyne.

Virsikirjan lisävihko, 2016, Kirkkohallitus/Sacrista, Helsinki.

Watson, J.R., 2013a, 'Kenneth George Finlay', in The Canterbury dictionary of hymnology, Canterbury Press, viewed 28 June 2016, from http://www.hymnology. co.uk/k/kenneth-george-finlay

Watson, J.R., 2013b, The Canterbury dictionary of hymnology, Canterbury Press, viewed 28 June 2016, from http://www.hymnology.co.uk/r/robert-archibaldsmith

Watson, J.R., 2013c, 'The Lord's my shepherd, I'll not want', in The Canterbury dictionary of hymnology, Canterbury Press, viewed 21 June 2016, from http:// www.hymnology.co.uk/t/the-lord's-my-shepherd,-i'll-not-want 